\title{
ANALISIS KERENTANAN LERENG LOKASI PEMBANGUNAN BENDUNGAN BENER KABUPATEN PURWOREJO
}

\section{SLOPE VULNERABILITY ANALYSIS OF BENER DAM CONSTRUCTION SITE, PURWOREJO REGENCY}

\author{
Daru Jaka Sasangka ${ }^{1 *}$, Suhardi ${ }^{1}$, Didit Puji Riyanto ${ }^{1}$, Dian Insani ${ }^{2}$, Cristina Dwi ${ }^{2}$ \\ ${ }^{1}$ Politeknik Pekerjaan U mum; JI. Prof Sudharto, Tembalang; (024)7472848 \\ ${ }^{2}$ Direktorat Jenderal Sumber Daya Air Kementerian PUPR, JI Pattimura N o.20 Kebayoran Baru
}

Received: 2021, August 29th

Accepted: 2021, N ovember $16^{\text {th }}$

\author{
Keywords: \\ AHP; \\ Geology of engineering; \\ Mitigation; \\ Slope vulnerability.
}

\section{Corespondent Email: \\ darujakasasangka@gmail.com}

\section{H ow to cite this article:}

Sasangka, D.J., Suhardi, Riyanto, D.P., Insani, D., \& Dwi, C.

(2021). Analisis Kerentanan Lereng Lokasi Pembangunan Bendungan Bener Kabupaten Purworejo. Jurnal Geofisika Eksplorasi, 07(03), 238-255.

\begin{abstract}
Abstrak. Bendungan Bener berdiri di Formasi Kebobutak (Tmok) yang merupakan produk vulkanisme. Belum ada studi mengenai kerentanan lereng lokasi pembangunan bendungan hingga saat ini, sehingga mitigasi kerentanan lereng perlu dilakukan. Mitigasi kerentanan lereng dipelukan untuk mendapatkan langkah pencegahan terjadinya longsor terutama selama proses konstruksi. Dasar Penentuan zona kerentanan mengacu data yang diperoleh dari overlay peta geologi teknik, peta kemiringan lereng, dan peta situasi lokasi konstruksi. Data tersebut antara lain kualitas massa batuan, kemiringan lereng, Intervensi konstruksi (galian baru) dan eksistensi penutup lahan serta tingkat pelapukan yang kemudian diolah dengan metode A nalytical Hierarchy Process (A HP). Hasil analisis menunjukan bahwa lokasi pembangunan Bendungan Bener terdiri dari empat zona kerentanan antara lain zona kerentanan lereng sangat rendah (5\%), zona kerentanan lereng rendah (25\%), zona kerentanan lereng sedang $(50 \%)$, dan zona kerentanan lereng tinggi (20\%) yang berada di sebelah barat dan timur bendungan inti. Bendungan Inti dan lokasi genangan dibangun di lokasi zona kerentanan sangat rendah hingga sedang, sehingga galian untuk bendungan inti tidak memerlukan penanganan khusus begitu juga lokasi genangan karena potensi sedimentasi dari pengaruh longsoran di sekitar bendungan kecil. Beberapa lokasi konstruksi seperti jalan akses yang melewati lokasi dengan kerentanan lereng tinggi memerlukan penanganan segera seperti dengan shortcrete.
\end{abstract}

\footnotetext{
Abstract The Bener Dam is located in the Kebobutak (Tmok). There is no study on the slope vulnerability of the dam construction site to date, so it was necessary to mitigate slope vulnerability. Slope vulnerability mitigation was needed to get steps to prevent landslides, especially during the construction process. The basis for determining the vulnerability zone is data obtained from overlaying engineering geology maps, slope maps, and construction site situation maps. The data include
} 
rock mass quality, slope, construction intervention, and the existence of land cover and weathering levels, which were then processed using the Analytical Hierarchy Process (AHP) method. The results of the analysis showed that the construction site of the Bener Dam consists of four vulnerability zones, including the very low (5\%), the low $(25 \%)$, the moderate $(50 \%)$, and the high slope vulnerability zone $(20 \%)$ which were located to the west and east of the main dam. The Main Dam and

(c) 2021 JGE (Jurnal Geofisika Eksplorasi). This article is an openaccess article distributed under the terms and conditions of the Creative Commons Attribution (CC BY NC) inundation locations are built in very low to moderate vulnerability zones so that excavations for the main dam don't require special treatment. Access roads construction that passes through sites with high slope vulnerability zones requires immediate treatment, such as shortcrete.

\section{PENDAHULUAN}

Bendungan bener merupakan bendungan yang direncanakan menjadi salah satu bendungan tertinggi di Indonesia (169 meter). Bendungan Bener merupakan bendungan yang akan dimanfaatkan antara lain untuk menjamin pemenuhan air irigasi untuk beberapa Daerah Irigasi (D.I.) di Kabupaten Purworejo dan memenuhi kebutuhan air baku sebesar $\pm 800 \mathrm{lt} / \mathrm{dt}$ untuk kebutuhan puncak sampai tahun 2050 di Kabupaten Purworejo (BBWS Serayu Opak, 2018). Melihat fungsi Bendungan Bener maka bendungan ini menjadi obyek vital negara. Berdiri di Formasi Kebobutak (Tmok) terdiri produk vulkanisme purba berupa batuan beku sangat menguntungkan dari sisi geologi namun untuk memastikan kestabilan lereng disekitar bendungan baik selama konstruksi dan masa operasi diperlukan banyak kajian lebih lanjut. Salah satu penelitian yang diperlukan adalah penilaian kerentanan lereng lokasi bendungan terutama lokasi galian selama konstruksi bendungan dan rencana lokasi genangan. Kerentanan tinggi perlu diwaspadai terlebih jika lokasi tersebut merupakan lokasi konstruksi sehingga diperlukan langkah pencegahan misal dengan memberikan shortcrete sebagai pencegahan terhadap ilfiltrasi air berlebih pada lereng.

Kecamatan Bener terdiri dari Zona Berpotensi Longsor Tipe B dan Zona Berpotensi Longsor Tipe C (Indriani dkk., 2017). Zona Berpotensi Longsor Tipe B merupakan daerah kaki gunung, kaki pegunungan, kaki bukit dan tebing sungai dengan kemiringan lereng berkisar antara 21\% sampai dengan $40 \%$, dengan ketinggian 500 meter sampai dengan 2000 meter di atas permukaan laut, sedangkan Zona Berpotensi Longsor Tipe C Zona berpotensi longsor pada daerah dataran tinggi, dataran rendah, dataran, tebing sungai, atau lembah sungai dengan kemiringan lereng berkisar antara 0\% sampai dengan 20\%, dengan ketinggian 0 sampai dengan 500 meter di atas permukaan laut (Menteri Pekerjaan Umum, 2007). Sebagian besar Kecamatan Bener merupakan Zona tipe $B$ dengan tingkat kerawanan sedang, dengan litologi breksi andesit dan kemiringan Lereng, agak curam (14\%-20\%) termasuk di kawasan Desa Ketosari yang berdekatan dengan lokasi penelitian di Desa Guntur (Indriani dkk., 2017). W ilayah Desa Ketosari yang didominasi batuan dasar breksi andesit memiliki kesamaan dengan daerah penelitian yang juga di dominasi oleh batuan penyusun breksi andesit (Sasangka dkk., 2020).

Kondisi kecamatan bener yang mana Bendungan Bener dibangun disana tidak terbebas dari potensi longsor, maka lokasi pembangunan bendungan diperlukan penelitian yang lebih detail yang memperhitungkan kondisi geologi teknik dan eksistensi penutup lahan yang belum pernah dilakukan sebelumnya.

Penyelidikan tanah pada Bendungan Bener berupa pemboran dalam lebih dari 30 titik sudah dilakukan antara rentan tahun 2015 hingga 2019, baik di lokasi bendungan inti 
maupun pada lokasi terowongan pengelak. Kondisi bawah permukaan dari korelasi data bor dalam dilokasi terowongan menunjukan adanya beberapa kondisi yang berbeda baik dari jenis batuan vulkanik dan kualitas massa batuannya. Perbedaan tersebut terutama perbedaan kualitas massa batuan sangat berpengaruh terhadap kestabilan terowongan menyebabkan perbedaan sistem penyangga yang dibutuhkan (Sasangka dkk., 2019)

Pemanfatan data geologi teknik permukaan belum dilakukan untuk analisa tingkat kerentanan lereng. Data permukaan dari pemetaan geologi teknik terutama data kualitas massa batuan dan tingkat kemiringan lereng dapat dijadikan parameter utama dalam penentuan tingkat kerentanan lereng (gerakan tanah) dilokasi pembangunan bendungan bener.

Dalam penentuan kerentanan lereng dengan beberapa parameter yang dianggap berpengaruh diperlukan bobot prioritas melalui metode proses hirarki analitik/Analytic $\mathrm{H}$ ierarchy Process (AHP). A nalisis kerentanan lereng dengan AHP dan beberapa faktor pengaruh akan efektif dengan melakukan overlay beberapa peta setelah pembobotan faktor pengaruh dilakukan (M isbahudin dkk., 2017).

Metode AHP menggunakan pendekatan statistik untuk membuat keputusan multi parameter, penggunaan AHP untuk kepentingan tertentu dapat menggunakan langkah-langkah yang dimulai dari pembuatan hirarki kemudian membuat matriks perbandingan (Sinarta dkk., 2016). Secara umum pembuatan hirarki dapat bersifat subyektif dari pengalaman dan kondisi yang terkait menyesuaikan kebutuhan dan analisa data. Penentuan nilai kepentingan parameter juga dengan melakukan intrepetasi yang mengacu pada skala kepentingan relatif. Pada lokasi pegunungan dengan material penyusun berumur Kuarter melibatkan tujuh parameter antara lain kelerengan, kondisi tanah, kerapatan struktur, curah hujan, tata air lereng, kegempaan dan vegetasi, kemudian seluruh parameter indikator tersebut dimasukan ke dalam matriks dan diberi nilai skala kepentingan yang disebut sebagai matriks normalisasi AHP. Keputusan dalam menentukan skala kepentingan pada analisis AHP harus diuji konsisitensinya dengan metode Eigenvector yang pertama dikenalkan oleh Saaty, (Sinarta dkk., 2016). Jika faktor Consistency Ratio $<10 \%$ atau 0,1 maka keputusan dalam menentukan tingkat kepentingan dapat diterima (Saaty, 2002).

$M$ etode penilaian tingkat kerentanan lereng dengan analytical hierarchy process (AHP) secara keruangan (spasial) dapat memunculkan faktor yang paling dominan memicu terjadinya gerakan tanah. Metode multi kriteria statistik ini membutuhkan banyak data sehingga hasil akan tergantung input datanya maka dari itu diperlukan normalisasi data dan nilai konsistensi rasio yang kecil untuk mendapatkan nilai dengan tingkat kepercayaan yang tinggi (Febriarta \& Wibowo, 2021).

Pada dasarnya dalam memilih paramater dapat menggunakan beberapa cara diantaranya dengan memperhatikan faktor penyebab longsoran secara umum berdasarkan Peraturan Menteri Pekerjaan Umum No.22/PRT/M/2007 diantranya curah hujan yang tinggi, lereng yang terjal, lapisan tanah yang kurang padat dan tebal, jenis batuan (litologi) yang kurang kuat, jenis tanaman dan pola tanam yang tidak mendukung penguatan lereng; getaran yang kuat (peralatan berat, mesin pabrik, kendaraan bermotor), susutnya muka air danau/bendungan, beban tambahan seperti konstruksi bangunan dan kendaraan angkutan, terjadinya pengikisan tanah atau erosi, adanya material timbunan pada tebing, bekas longsoran lama yang tidak segera ditangani, adanya bidang diskontinuitas, penggundulan hutan, dan/atau daerah pembuangan sampah. 
Penentuan parameter longsoran untuk analisis AHP juga dapat dengan membuat kuisioner penilaian ahli terhadap derajat kepentingan parameter yang ditampilkan dalam bentuk matriks perbandingan (Ercanoglu dkk., 2008).

Pengetahuan tingkat kerentanan lereng dapat digunakan untuk antisipasi terhadap potensi gerakan tanah terutama pada kerentanan tinggi sehingga saat konstruksi dilakukan pada lokasi tersebut dapat dipersiapkan penananganan.

\section{TINJAUAN PUSTAKA}

Stabilitas lereng dikontrol beberapa parameter anatara lain kekuatan material penyususun lereng baik tanah maupun batu, kemiringan lereng, kondisi air tanah maupun intervensi terhadap lereng tersebut. Perbedaan kondisi tersebut menyebabkan perbedaan stabilitas lereng yang secara otomatis juga menyebabkan perbedaan tingkat kerentanan lerengnya. Daerah penelitian yang sebagian besar tersusun atas batuan vulkanik sehingga parameter kekuatannya dikontrol oleh kualitas massa batuannya. Penentuan kualitas massa batuan ditentukan dengan Rock Mass Rating (RM R).

Selain jenis litologi dan kaulitas massa batuan yang berbeda, lokasi penelitian memiliki kemiringan lereng, tingkat pelapukan batuan dan eksistensi penutup lahan yang berbeda. Penentuan kerentanan lereng dilakukan dengan cara overlay map antara beberapa peta yang memiliki informasi dianggap mempunyai kontribusi terhadap stabilitas lereng seperti peta geologi teknik yang menunjukan kualitas massa batuan dan tingkat pelapukan, peta kemiringan lereng dan peta situasi yang menunjukan eksistensi penutup lahan serta lokasi yang terintervensi langsung karena galian konstruksi di lokasi bendungan. Pada penelitian ini penentuan kerentanan lereng menggunakan parameter yang mempunyai kontribusi terhadap stabilitas lereng tersebut di atas yang kemudian di bobotkan untuk masing-masing kondisinya. Penentuan kerentanan tidak dengan melakukan perhitungan numerik faktor keamanan pada lokasi penelitian.

Setiap kondisi yang meliputi kualitas massa batuan, kemiringan lereng, tingkat pelapukan dan penutup lahan memiliki tingkat pengaruh yang berbeda, begitu juga masing masing kondisi yang termuat pada setiap peta memiliki kontribusi resiko yang berbeda (Tabel 1). Maka dibutuhkan suatu analisis yang dapat mengeluarkan bobot dari 4 parameter utama, sehingga bobot tersebut pada akhirnya dapat digunakan sebagai faktor pengali dari kondisi masing-masing parameter.

Tabel. 1. Kelas Kerentanan M asing-M asing Kondisi Setiap Parameter.

\begin{tabular}{|c|c|c|c|c|}
\hline $\begin{array}{c}\text { Kualitas M assa } \\
\text { Batuan }\end{array}$ & $\begin{array}{c}\text { Kemiringan } \\
\text { Lereng }\end{array}$ & Tata Guna Lahan & $\begin{array}{l}\text { Tingkat } \\
\text { Pelapukan }\end{array}$ & Kelas Kerentanan \\
\hline $\begin{array}{l}\text { Good - Very Good } \\
\text { Rock Breksi Andesit }\end{array}$ & $\begin{array}{c}\text { Datar - M iring } \\
\left(0^{\circ}-8^{\circ}\right)\end{array}$ & Tegalan/ H utan & $\begin{array}{c}\text { Fresh - } \\
\text { M oderately } \\
\text { W eathered }\end{array}$ & $\begin{array}{c}1 \\
\text { (Sangat Rendah) }\end{array}$ \\
\hline Good - Very Good & Agak Curam & & Highly & 2 \\
\hline Rock Breksi Polimik & $\left(8^{\circ}-16^{\circ}\right)$ & & W eathered & ( Rendah) \\
\hline $\begin{array}{c}\text { Fair Rock M ass } \\
\text { Quality }\end{array}$ & $\begin{array}{l}\text { Curam } \\
\left(16^{\circ}-35^{\circ}\right)\end{array}$ & Pemukiman & & $\begin{array}{c}3 \\
\text { (Sedang/M enengah ) }\end{array}$ \\
\hline $\begin{array}{l}\text { Undifine Rock M ass } \\
\text { Quality (Residual } \\
\text { Soil) }\end{array}$ & $\begin{array}{l}\text { Sangat Curam } \\
\left(35^{\circ}-55^{\circ}\right)\end{array}$ & $\begin{array}{l}\text { Wilayah } \\
\text { Konstruksi }\end{array}$ & $\begin{array}{l}\text { Completely } \\
\text { W eathered }\end{array}$ & $\begin{array}{c}4 \\
\text { (Tinggi) }\end{array}$ \\
\hline
\end{tabular}


Pembobotan menggunakan metode Analytical Herarchy Process (AHP) yaitu teori pengukuran melalui perbandingan berpasangan dan bergantung pada penilaian para ahli untuk memperoleh skala prioritas. AHP termasuk dalam metode semi kualitatif yang pada prinsipnya digunakan untuk menyederhanakan persoalan menjadi suatu hierarki yang sistematis mempertimbangkan banyak faktor sehingga di dapat keputusan alternatif paling baik (Saaty, 2002). Langkah untuk melakukan metode AHP adalah sebagai berikut (Saaty, 2002):

a. Mengumpulkan semua parameter yang memberikan pengaruh terhadap masalah dan solusi yang ada.

b. Membuat hirarki faktor yang paling penting dari semua faktor hingga yang paling tidak memberikan dampak.

c. Merancang pairwise comparison atau matriks perbandingan berpasangan untuk menggambarkan intensitas pengaruh setiap elemen menggunakan skala kepentingan yang ditunjukkan pada Tabel 2.

d. Membuat pembobotan setiap kriteria dan kepentingan sesuai dengan tingkat konsistensi hirarki kemudian menghitung nilai eigen dan menguji konsistensinya dengan Persamaan 1, Persamaan 2 dan Persamaan 3.

$$
\begin{aligned}
& \lambda_{\max }=(\mathrm{A} \times \mathrm{U})+(\mathrm{B} \times \mathrm{V})+ \\
& (\mathrm{C} \times \mathrm{W})+(\mathrm{D} \times \mathrm{X}) \\
& \mathrm{CI}=\frac{\lambda_{\max }-\mathrm{n}}{\mathrm{n}-1} \\
& \mathrm{CR}=\frac{C I}{R I}
\end{aligned}
$$

$\lambda_{\max }$ merupakan nilai Eigen maksimal dari matriks, $\mathrm{n}$ adalah orde matriks, dan RI adalah adalah random index berdasarkan matriks. Perbedaan nilai random index tergantung pada orde matriks yang digunakan, dimana nilai tersebut dapat dilihat pada Tabe 3 (Pratiwi, 2019). Nilai jumlah rasio awal dan jumlah normalisasi digunakan untuk menentukan nilai eigen maksimal dari matriks nilai Consistency Index $(\mathrm{Cl})$, dan Consistency Ratio (CR) dengan menggunakan Persamaan 1, Persamaan 2, dan Persamaan 3. Pembobotan dapat diterima jika nilai Consistency Ratio (CR) $<10 \%$.

Tabel 2. Skala kepentingan elemen dalam penghitungan metode AHP.

\begin{tabular}{cc}
\hline Tingkat Kepentingan & Definisi \\
\hline 1 & Sama penting \\
2 & Lemah atau sedikit penting \\
3 & Sedang \\
4 & Lebih dari sedang \\
5 & Penting \\
6 & Lebih dari Penting \\
7 & Jelas Lebih Penting \\
8 & Sangat, sangat kuat \\
9 & Sangat penting
\end{tabular}

Tabel 3. Nilai random index (RI) berdasarkan orde matriks.

\begin{tabular}{ccccccccc}
\hline Jumlah O rde & 3 & 4 & 5 & 6 & 7 & 8 & 9 & 10 \\
\cline { 1 - 7 } Nilai RI & 0,58 & 0,9 & 1,12 & 1,24 & 1,32 & 1,41 & 1,45 & 1,49 \\
\hline
\end{tabular}


Selain pembobotan metode ini menggunakan empat kelas dengan menggunakan nilai batas atas (upper bound) untuk tiap kelas, yaitu zona kerentanan gerakan tanah sangat rendah, zona kerentanan gerakan tanah rendah, zona kerentanan gerakan tanah menengah, dan zona kerentanan gerakan tanah tinggi, yang kemudian dikalikan dengan faktor bobot yang sudah dibuat (Standar Nasional Indonesia, 2005). Hasil yang detail dan akurat memerlukan overlay peta. Masing-masing parameter pada setiap peta memiliki kelas kerentanan, sehingga perkalian antara nilai skor kerentanan yang terdiri dari 4 kelas diatas dan bobot dari hasil analisis AHP di lakukan di setiap grid peta sebelum dibuat peta kerentanan lereng yang utuh.

Penentuan kerentanan lereng dengan metode AHP digunakan oleh beberapa peneliti. Lokasi Jalan Nasional Jalur Ponorogo Trenggalek yang terdiri dari beberapa satuan batuan beku, dan dengan tingkat alterasi yang beragam, menggunakan analisis AHP berdasarkan beberapa parameter data antara lain Kondisi Alterasi, Kemiringan Lereng, Kualitas Massa Batuan dan Jenis Penutup Lahan untuk menentukan zona kerentanan lereng. Kondisi alterasi memiliki faktor pengaruh yang paling signifikan terhadap kerentanan lereng, kemudian Kemiringan Lereng, Kualitas Massa Batuan dan Jenis Penutup Lahan, dimana Zona kerentanan tinggi berada pada lokasi dengan intensitas alterasi yang intensif sehingga semakin menurunkan kualitas batuan (Pratiwi, 2019). Penentuan parameter input data antara satu tempat dan tempat lain sangat mungkin berbeda, terutama pada lokasi penelitian yang tidak mengalami alterasi hidrotermal seperti disebutkan di atas maka parameter yang paling signifikan akan lain. Salah satu penentuan parameter utama dapat ditentukan dengan melihat longsoran di lokasi eksisting. Faktor pengontrol utama ketidakstabilan lereng longsoran lokasi eksisting pada penelitian ini adalah kualitas massa batuan.

Analisis kerentanan lereng dengan pembobotan menggunakan meotde AHP pernah dilakukan di Kecamatan Sukatani dan di Kecamatan Plered, Kabupaten Purwakarta. Lokasi tersebut secara geologi didominasi oleh soft rock yang termasuk batuan sedimen antara lain batulempung, batupasir, dan breksi piroklastik (M isbahudin dkk., 2017). Pada penelitian tersebut menggunakan parameter geologi secara umum seperti litologi, struktur geologi, kemiringan lereng, relief relatif, kebasahan lahan dan penutup lahan, dimana parameter dominan yang memiliki bobot paling besar dalam analisis adalah faktor kemiringan lereng, kemudian jenis litologi, keberadaan struktur geologi, kebasahan lahan, tutupan lahan dan terakhir relief relatif sebagai parameter yang paling tidak dominan. Lokasi penelitian tersebut sebagian besar (80\%) berada pada lokasi dengan kemiringan $<15^{\circ}$, sehingga zona kerentanan sangat rendah hingga rendah mendominasi lokasi penelitian (84\% dari total luas area penelitian). Sementara itu, pada lokasi yang termasuk dalam tingkat kerentanan menengah hingga tinggi dijumpai longsoran yang cukup membahayakan di daerah penelitiannya (M isbahudin dkk., 2017).

Untuk daerah penelitian dengan cakupan area yang tidak begitu luas (area konstruksi bendungan) dimana variasi litologi dan kemiringan lerang yang sederhana, maka dua parameter tersebut dapat diturunkan dampak kepentingannya. Lokasi bendungan memiliki variasi kualitas massa batuan yang beragam (Sasangka, 2021). Dari kondisi tersebut maka kualitas massa batuan yang didalamnya termasuk memuat jenis litologi menempati prioritas pertama tingkat kepentingan terhadap stabilitas lereng, selain melihat bahwa adanya longsoran eksisting di sekitar lokasi bendungan dikontrol oleh kualitas massa 
batuan yang rendah atau mengikuti patahan yang ada. Faktor kemiringan lereng memiliki pengaruh yang signifikan selanjutnya kemudian setelahnya faktor eksistensi penutup lahan dan faktor tingkat pelapukan batuan.

Empat aspek dipertimbangkan dalam menentukan zonasi kerentanan lereng pada penelitian ini, empat aspek tersebut menyesuaikan kondisi lokasi penelitian berdasarkan penelitian terdahulu yang pernah dilakukan. Empat aspek yang diperhitungkan antara lain kualitas massa batuan, kemiringan lereng, eksistensi lahan termasuk didalamnya Intervensi konstruksi (galian baru) dan tingkat pelapukan.

\section{METODE PENELITIAN}

Dalam penelitian ini memperhitungkan empat parameter utama dalam menentukan tingkat kerentanan lereng terhadap longsor yaitu kualitas massa batuan, kemiringan lereng, eksistensi lahan termasuk didalamnya intervensi konstruksi (galian baru) dan tingkat pelapukan. Data kualitas massa batuan dan tingkat pelapukan didapatkan dari survey pemetaan di lapangan. Data kemiringan lereng didapat dari analisis topografi dan pengamatan lapangan. Sedangkan Intervensi konstruksi (galian baru) dan Eksistensi penutup lahan dari pengamatan lapangan dan peta situasi lokasi proyek.
Empat paramater kualitas massa batuan, kemiringan lereng, intervensi konstruksi (galian baru) dan eksistensi penutup lahan, dan tingkat pelapukan dianalisis skala kepentingan satu sama lain sesuai Tabel $\mathbf{2}$ sehingga meendapatkan rasio perbandingan awal AHP yaitu nilai A (variabel kualitas massa batuan), B (variabel kemiringan lereng), C (variabel eksistensi penutup lahan) dan $\mathrm{D}$ (variabel tingkat pelapukan) (Tabel $\mathbf{4}$ dan Tabel 5). Keempat variabel diatas digunakan untuk membagi masing-masing nilai perbandingan tingkat kepentingan antar parameter yang tersaji di tabel 4 sehingga didapatkan normalisasi AHP (Tabel 6). Dari tabel normalisasi didapatkan variabel jumlah normalisasi yaitu $U$ (variabel kualitas massa batuan), V (variabel kemiringan lereng), W (variabel eksistensi penutup lahan) dan $X$ (variabel tingkat pelapukan) (Tabel 7). Variabel Jumlah rasio awal AHP dan variabel jumlah normalisasi A HP untuk masing masing parameter digunakan untuk menghitung nilai eigen maksimal dari matriks sesuai dengan persamaan 3, yang kemudian digunakan untuk perhitungan Consistency Index $(\mathrm{Cl})$ dan Consistency Ratio (CR). Jumlah normalisasi masing masing parameter (Tabel 7) juga digunakan sebagai bobot pengali kelas tingkat kerentanan masing masing kondisi di setiap parameter (Tabel $\mathbf{1}$ ).

Tabel 4. T abel rasio perbandingan awal AHP.

\begin{tabular}{ccccc}
\hline Parameter & $\begin{array}{c}\text { Kualitas M assa } \\
\text { Batuan }\end{array}$ & $\begin{array}{c}\text { Kemiringan } \\
\text { Lereng }\end{array}$ & $\begin{array}{c}\text { Intervensi Konstruksi (Galian } \\
\text { Baru) dan Eksistensi Penutup } \\
\text { Lahan }\end{array}$ & $\begin{array}{c}\text { Tingkat } \\
\text { Pelapukan }\end{array}$ \\
\hline Kualitas M assa Batuan & 1 & 3 & 4 & 5 \\
Kemiringan Lereng & 0,33 & 1 & 2 & 4 \\
$\begin{array}{c}\text { Intervensi konstruksi } \\
\text { (galian baru) dan }\end{array}$ & 0,25 & 0,5 & 1 & 2 \\
Eksistensi penutup & & & & \\
lahan & 0,2 & 0,25 & 0,5 & 1 \\
Tingkat Pelapukan & 1,78 & 4,75 & 7,5 & 12 \\
Jumlah & $\mathrm{A}$ & $\mathrm{B}$ & $\mathrm{C}$ & $\mathrm{D}$ \\
Variabel & & & &
\end{tabular}


Tabel 5. Tabel jumlah rasio awal.

\begin{tabular}{ccccc}
\hline Parameter & $\begin{array}{c}\text { Kualitas Massa } \\
\text { Batuan }\end{array}$ & Kemiringan Lereng & $\begin{array}{c}\text { Tingkat } \\
\text { Pelapukan }\end{array}$ & $\begin{array}{c}\text { Intervensi Konstruksi dan } \\
\text { Eksistensi Penutup Lahan }\end{array}$ \\
\hline Jumlah & 1,78 & 4,75 & 7,5 & 12 \\
Variabel & A & B & C & D
\end{tabular}

Tabel 6. N ormalisasi AHP.

\begin{tabular}{|c|c|c|c|c|c|c|c|}
\hline Parameter & $\begin{array}{c}\text { Kualitas } \\
\text { Massa } \\
\text { Batuan }\end{array}$ & $\begin{array}{l}\text { Kemiringan } \\
\text { Lereng }\end{array}$ & $\begin{array}{c}\text { Intervensi } \\
\text { Konstruksi } \\
\text { (Galian } \\
\text { Baru) dan } \\
\text { Eksistensi } \\
\text { Penutup } \\
\text { Lahan }\end{array}$ & $\begin{array}{l}\text { Tingkat } \\
\text { Pelapukan }\end{array}$ & Jumlah & $\begin{array}{c}\text { Bobot } \\
\text { Parameter }\end{array}$ & Variabel \\
\hline $\begin{array}{c}\text { Kualitas M assa } \\
\text { Batuan }\end{array}$ & 0,56 & 0,63 & 0,53 & 0,42 & 2,14 & 0,57 & U \\
\hline $\begin{array}{l}\text { Kemiringan } \\
\text { Lereng }\end{array}$ & 0,19 & 0,21 & 0,27 & 0,33 & 1 & 0,25 & V \\
\hline $\begin{array}{c}\text { Intervensi } \\
\text { Konstruksi } \\
\text { (Galian Baru) dan } \\
\text { Eksistensi } \\
\text { Penutup Lahan }\end{array}$ & 0,14 & 0,11 & 0,13 & 0,17 & 0,55 & 0,14 & W \\
\hline $\begin{array}{c}\text { Tingkat } \\
\text { Pelapukan }\end{array}$ & 0,11 & 0,05 & 0,07 & 0,08 & 0,28 & 0,07 & $x$ \\
\hline Jumlah & 1,00 & 1,00 & 1,00 & 1,00 & 3,97 & 1,00 & \\
\hline
\end{tabular}

Tabel 7. Jumlah N ormalisasi.

\begin{tabular}{ccccc}
\hline Parameter & $\begin{array}{c}\text { Kualitas M assa } \\
\text { Batuan }\end{array}$ & $\begin{array}{c}\text { Kemiringan } \\
\text { Lereng }\end{array}$ & Tingkat Pelapukan & $\begin{array}{c}\text { Intervensi Konstruksi } \\
\text { dan Eksistensi Penutup } \\
\text { Lahan }\end{array}$ \\
\hline Jumlah & 0,57 & 0,25 & 0,14 & 0,07 \\
Variabel & $\mathrm{U}$ & $\mathrm{V}$ & $\mathrm{W}$ & $\mathrm{X}$
\end{tabular}

Skor kondisi pada masing masing paraneter (Tabel 1) dikalikan dengan bobot parameter (Tabel 7) didapatkanlah nilai tingkat kerentanan. Penilaian tingkat kerentanan menggunakan nilai acuan dari 1 hingga 4 sesuai dengan Standar Nasional Indonesia, dimana nilai 3-4 merupakan zona kerentanan gerakan tanah tinggi, nilai 2-3 merupakan zona kerentanan gerakan tanah sedang, nilai 1-2 merupakan zona kerentanan gerakan tanah rendah, dan nilai 0-1 merupakan zona kerentanan gerakan sangat rendah. Nilai tersebut didapatkan dari penjumlahan hasil perkalian antara skor tingkat kerentanan masing-masing parameter dengan bobot.

Penilaian tingkat kelas kerentanan menentukan dalam penilaian tingkat kerentanan ditentukan dengan perhitungan nilai rock mass rating (RMR) permukaan (Tabel 8). 
Tabel 8. Rating kualitas masa batuan RM R ((Bieniawski, 1989) dalam (Todd, 2014)).

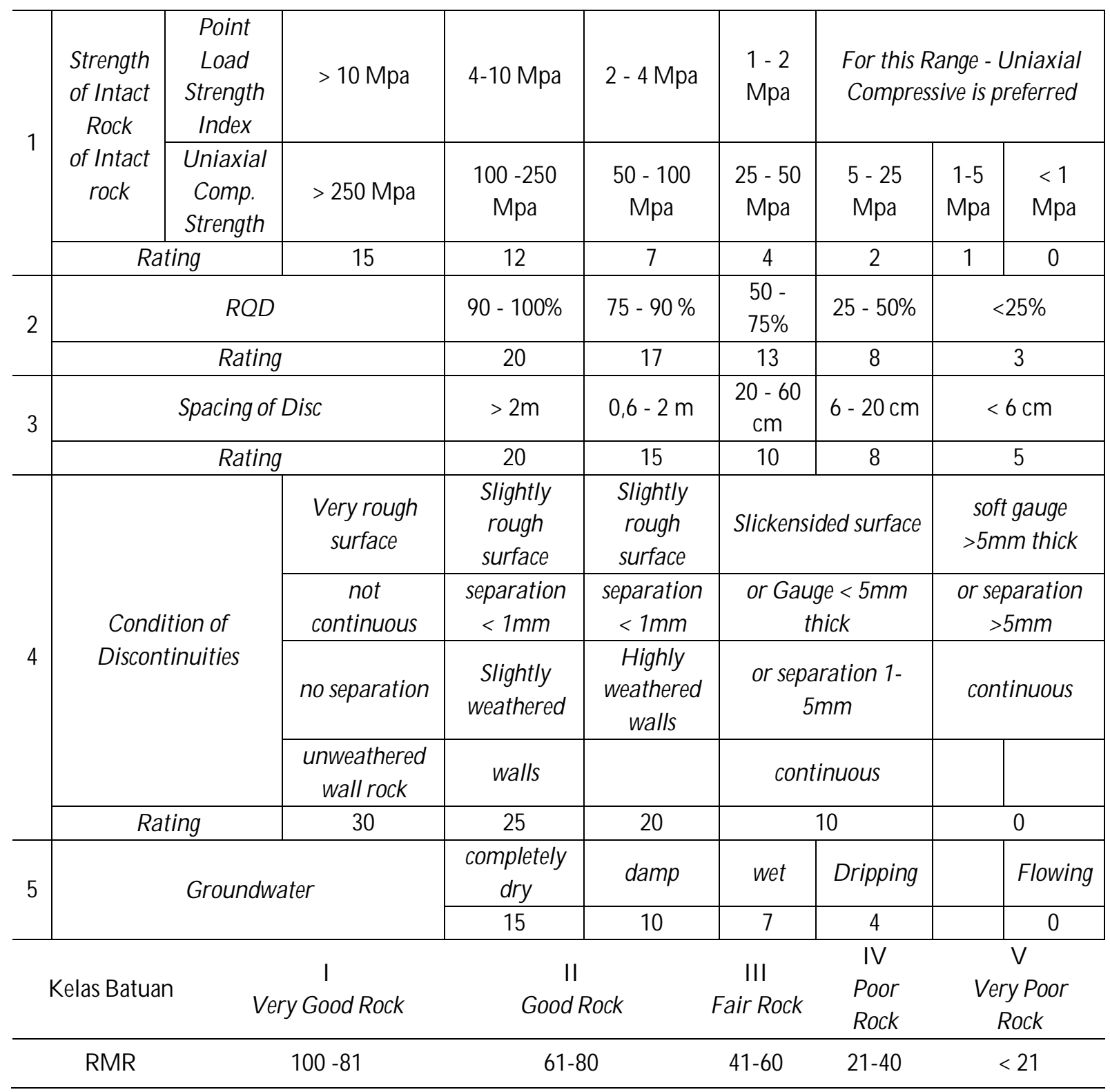


Tabel 9. Derajat pelapukan batuan (BS5930, 1981).

\begin{tabular}{|c|c|c|}
\hline Term & Description & Degree \\
\hline Fresh & $\begin{array}{l}\text { No visible sign of rock material weathering; perhaps slight } \\
\text { discolouration on major discontinuity surface }\end{array}$ & 1 \\
\hline $\begin{array}{c}\text { Slightly } \\
\text { W eathered }\end{array}$ & $\begin{array}{c}\text { Disscolouration indicates weathering of rock material and } \\
\text { discontinuity surface. All rock material may be discoloured by } \\
\text { weathering }\end{array}$ & II \\
\hline $\begin{array}{l}\text { Moderately } \\
\text { Weathered }\end{array}$ & $\begin{array}{l}\text { Less than half of the rock material is decomposed or disintegrated to a } \\
\text { soil. Fresh or discoloured rock is present either as a continuous } \\
\text { framework or as core stones }\end{array}$ & III \\
\hline $\begin{array}{l}\text { Highly } \\
\text { weathered }\end{array}$ & $\begin{array}{c}\text { More than half of rock material is decomposed or disintegrated to a } \\
\text { soil. Fresh or discoloured rock is present either as a discontinous } \\
\text { framework as core stones. }\end{array}$ & IV \\
\hline $\begin{array}{l}\text { Completely } \\
\text { W eathered }\end{array}$ & $\begin{array}{c}\text { All rock material is decomposed and/or disintegrated to soil. The } \\
\text { original mass structure is still largely intact. }\end{array}$ & V \\
\hline Residual Soil & $\begin{array}{l}\text { All rock material is converted to soil. The mass structure and material } \\
\text { fabric is destroyed. There isa large change in volume. But the soil has } \\
\text { not been significantly transported. }\end{array}$ & VI \\
\hline
\end{tabular}

Peta kerentanan lereng terhadap longsoran didapatkan dengan overlay map beberapa peta. Peta geologi teknik lokasi penelitian mewakili kondisi kualitas massa batuan dan tingkat pelapukan. Peta geomorfologi memberikan informasi kemiringan lereng dan peta situasi lokasi proyek memberikan informasi Intervensi konstruksi (galian baru) dan Eksistensi penutup lahan. Tingkat pelapukan dapat dilihat pada peta geologi teknik dimana penentuan kerentanan berdasarkan beberapa karakteristik (Tabel 9) (BS 5930, 2009).

\section{HASIL DAN PEMBAHASAN}

Breksi Vulkanik Andesit dan Breksi Polimik merupakan penyusun utama lokasi pembangunan bendungan yang termasuk dalam Formasi Kebobutak (Tmok), dari data permukaan lokasi bendungan inti dan terowongan berada pada breksi vulkanik andesit (Sasangka dkk., 2020). Data Litologi saja tidak cukup untuk menjadi parameter dalam penentuan zona kerentanan lereng oleh karena itu diperlukan informasi yang dalam yang lebih mempengaruhi kestabilan lereng setempat oleh karena itu kemudian data kualitas massa batuan permukaan digunakan. Data kualitas massa batuan permukaan dan paremeter tingkat pelapukan dapat dilihat pada peta geologi teknik (Gambar $\mathbf{1}$ ).

Kualitas Massa batuan dibagi menjadi lima baik berdasarkan klasifikasi Rock Mass Rating (RM R) maupun Klasifikasi Geological Strenght Index (GSI) antara lain kualitas massa batuan sangat baik dengan nilai RM R 100-81 atau nilai GSI 76-95, Kualitas massa batuan baik dengan nilai RM R 61-80 atau nilai GSI 56-75, kualitas massa batuan sedang dengan nilai RM R 41-60 atau nilai GSI 41-55, kualitas massa batuan buruk dengan nilai RMR atau GSI 21-40 dan kualitas massa batuan sangat buruk dengan nilai RMR atau GSI < 21 (Sivakugan, N. Kumar, S. Das, 2004). Lokasi penelitian menggunakan terdiri dari tiga kualitas massa batuan dari sedang - hingga sangat baik, sedangkan baruan yang sudah terubah secara keseluruhan tidak bisa lagi dinilai kualitas massa batuannya dan termasuk kedalam tanah residu.

Penelitian tidak menggunakan GSI untuk menentukan kualitas massa batuan di 
lapangan, karena kondisi batuan beku adalah anisotropik sehingga potensi keruntuhannya adalah kinematik, dan GSI lebih baik digunakan untuk kondisi batuan yang isotropik (Hoek \& Brown, 2019). Slope M ass Rating (SMR) merupakan salah satu metode penilaian kestabilan lereng yang berbasis kualitas massa batuan efektif digunakan utuk menentukan kelas kestabilan lereng batuan dengan tipe keruntuhan kinematik (Romana dkk., 2015). SMR tidak digunakan untuk menilai tingkat kerentanan lereng di artikel ini karena penerapannya harus detail pada lokasi lokasi tertentu yang sifatnya lokal dan dapat dikembangkan pada penelitian selanjutnya.



Gambar 1. Peta geologi teknik lokasi penelitian.

Peta geologi teknik yang memuat kualitas massa batuan juga memberikan informasi tingkat pelapukan. Breksi andesit completely weathered - residual soil menempati $\pm 20 \%$ dari semua lokasi penelitian. Breksi andesit fair rock highly weathered menempati $\pm 15 \%$ dari 
semua lokasi penelitian. Breksi andesit fair rock fresh rock - moderately weathered menempati $\pm 10 \%$ dari semua lokasi penelitian. Breksi andesit Good rock - very good rock fresh rock - moderately weathered menempati $\pm 30 \%$ dari semua lokasi penelitian. Breksi polimik Good rock - very good fresh rock - slightly weathered menempati $\pm 5 \%$ dari semua lokasi penelitian. Breksi polimik fair rock moderately - highly weathered menempati $\pm 10 \%$ dari semua lokasi penelitian. Di lokasi penelitian terdapat lokasi sisa longsoran pada kualitas massa batuan sedang (fair rock), hal ini menjadi salah satu faktor tingkat kepentingan terhadap longsoran kualitas massa batuan menjadi paling tinggi selain karena memang dominasi lokasi penelitian merupakan batuan dibandingkan tanah.

Data kemiringan lereng didapatkan dari analisa peta topografi, klasifikasi kemiringan lereng dibagi menjadi datar atau hampir datar, landai, miring, agak curam, curam, sangat, curam, curam ekstrim (Zuidam, 1986), namun untuk keperluan penelitian dan berdasarkan kondisi maka disederhanakan menjadi empat klasifikasi yaitu Sangat Curam (350-550), Curam (160-350), Agak Curam (80-160), Datar - M iring (00-80) (Tabel 7). Berdasarkan peta kemiringan lereng ini terlihat bahwa sebagian besar lokasi penelitian masuk kedalam kemiringan lereng curam sekitar 50\% (Gambar 2).

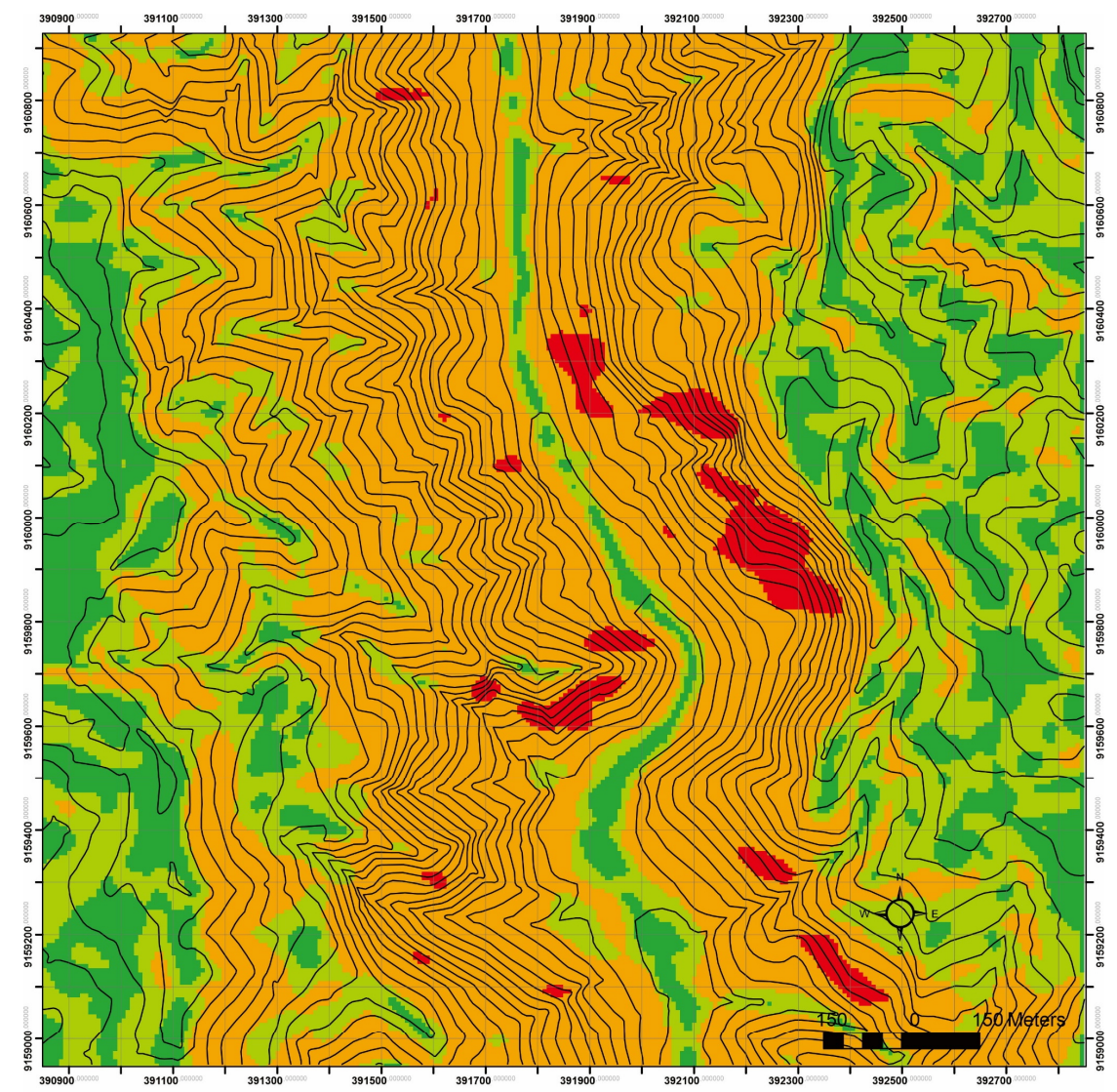

\section{Legenda}

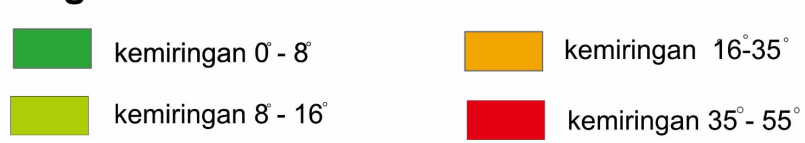

Gambar 2. Peta kemiringan lereng. 
Peta kerentanan lereng terhadap longsoran dibuat dengan memperhitungkan faktorfaktor diatas dan melihat pemanfaatan lahan, kemudian perhitungan pembobotan dengan analisis AHP. Pembobotan dapat diterima setalah perhitungan dengan persamaan (3) didapatkan nilai CR 0,0066. Nilai CR 0,0066 memenuhi syarat agar AHP dapat diterima yaitu $C R<10 \%$ sehingga analisis A H P ini dapat diterima sebagai metode pembobotan 4 parameter utama. Pemetaan detail yang digunakan untuk parameter masukan analisis kerentanan lereng memberikan data yang baik dalam klasifikasi kerentanan lereng. Hasil analisis menunjukan bahwa lokasi penelitian yaitu merupakan wilayah pembangunan bendungan bener disusun oleh 4 zona kerentanan antara lain zona kerentanan Ireng sangat rendah (5\%), zona kerentanan lereng rendah (25\%), zona kerentanan lereng sedang (50\%), zona kerentanan lereng tinggi (20\%) (Gambar 3).

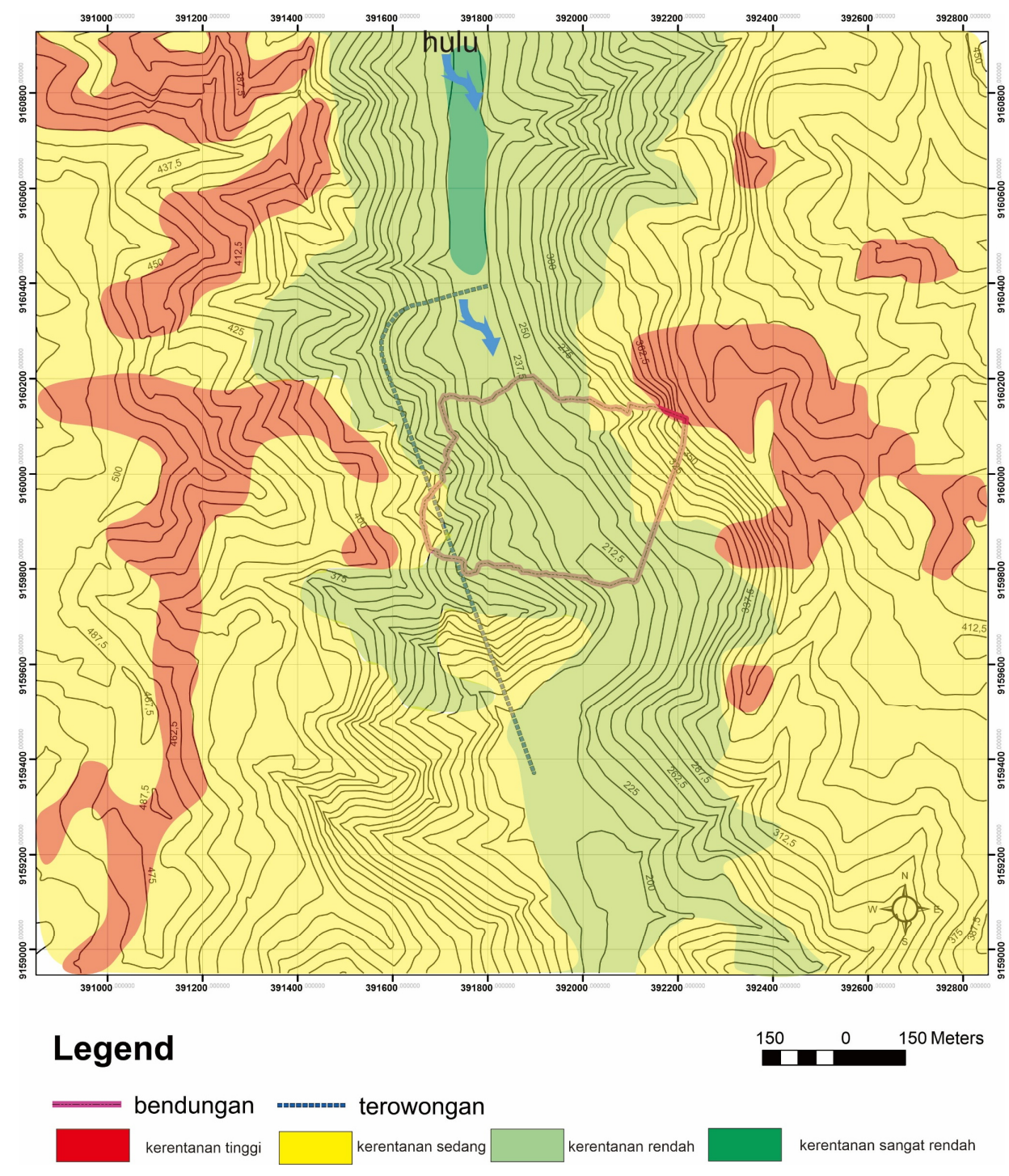

Gambar 3. Zona kerentanan lereng lokasi pembangunan Bendungan Bener dan sekitarnya. 


\subsection{Kerentanan Sangat Rendah- Rendah}

Lokasi dengan tingkat kerentanan sangat rendah hingga rendah menempati $\pm 30 \%$ dari total luas wilayah penelitian. Lokasi ini berada pada daerah aliran sungai dan sekitarnya yang secara umum terdiri dari batuan breksi andesit dengan kualitas massa batuan yang baik hingga sangat baik. Sebagian besar lokasi pembangunan bendungan, terowongan dan lokasi genangan bendungan berada pada zona kerentanan rendah yang berada pada bagian tengah lokasi penelitian membentang dari utara ke selatan (Gambar 3).

Lokasi ini berada di daerah pada elevasi yang lebih rendah dibandingkan dengan lokasi lain di area penelitian. Faktor elevasi ini juga yang kemudian mendukung tingkat pelapukan batuan disana tetap rendah bahkan tidak lapuk, dan tanah penutup sangat tipis sehingga tejadinya longsor sangat kecil kemungkinannya. Lokasi pembangunan bendungan inti sebagian besar berada pada lokasi dengan tingkat kerentanan rendah.

Lokasi genangan bendungan yang berada di sebelah utara dari bendungan inti, dimana elevasi maksimalnya tidak lebih tinggi dari elevasi bendungan inti berada pada tingkat kerentanan lereng yang rendah, sehingga jika terjadi rapid draw down pada lokasi genangan kemungkinan kecil mempengaruhi stabilitas dari lereng di sekitar genangan.

\subsection{Kerentanan Seclang}

Lokasi dengan tingkat kerentanan sedang mendominasi daerah penelitian dengan tingkat $( \pm 50 \%)$. Lokasi pembangunan inti bendungan sebagian kecil berada pada zona kerentanan lereng sedang, termasuk lokasi pembangunan terowongan. Zona kerentanan lereng sedang dapat terjadi pada lokasi yang tersusun oleh residual soil yang tebal dengan kemiringan lereng agak curam hingga curam. Zona kerentanan lereng sedang juga dapat berada pada tempat yang material lerengnya batuan namun tesusun dengan kualitas massa batuan menengah, dengan tingkat pelapukan tinggi dan kemiringan lereng yang curam, kondisi seperti itu akan menjadi lebih rentan (menjadi kerentanan tinggi) jika terdapat kegiatan penggalian disana. Zona kerentanan lereng sedang yang berada pada lokasi pembangunan bendungan maupun genangan sangat sedikit, selama tidak tersusun atas residual soil yang tebal dan tidak ada intervensi konstruksi maka zona ini cukup aman baik selama konstruksi maupun operasi bendungan, namun perkuatan pada lokasi-lokasi yang memang membutuhkan terutama jika terdapat penggalian di sana. Zona kerentanan lereng sedang berada di sebelah timur dan barat lokasi bendungan inti dengan elevasi yang lebih tinggi membentang dari utara ke selatan.

\subsection{Kerentanan Tinggi}

Zona kerentanan tinggi yang menempati sebagian kecil lokasi penelitian ( $\pm 20 \%$ ) berada pada morfologi yang curam hingga sangat curam yang tersusun oleh material residual soil, Keberadaan intervensi konstruksi (galian baru) pada lokasi dengan kualitas massa batuan sedang juga menyebabkan tingkat kerentanan menjadi tinggi. Zona kerentanan lereng tinggi berada setempat-setempat di sebelah timur dan barat lokasi bendungan inti dengan elevasi yang lebih tinggi. Kualitas massa batuan yang dikontrol oleh struktur geologi memiliki pengaruh yang signifikan bahkan pada batuan completely weathered hingga residual soil pola runtuhannya masih mengikuti kemenerusan struktur geologi pada batuan asalnya (Gambar 4). Lokasi dengan tingkat kerentanan tinggi dapat dilakukan penanganan pada saat penggalian seperti dengan melakukan penutupan lereng dengan shortcrete (Gambar 4).

\subsection{Verifikas MetodeAHP}

Pembobotan menggunakan metode Analytical Herarchy Process (AHP) dapat diterima jika nilai consistency ratio (CR) $<10 \%$ 
atau $<0,1$. Nilai $C R$ untuk penelitian ini adalah Nilai CR 0,0066.

Beberapa penelitian serupa menunjukan nilai yang berbeda sebagai contoh penelitan yang dilakukan di lokasi gunung api kuarter, Gunung Batur di Bali dengan menggunakan tujuh parameter antara lain kelerengan, kondisi tanah, kerapatan struktur, curah hujan, tata air lereng, kegempaan dan vegetasi, memunculkan kelerengan dan tata air tanah sebagai parameter dominan memiliki nilai $C R$ 0,053 (Sinarta dkk., 2016). Kaldera Gunung Batur yang memiliki kelerangan paling curam yang berada pada 500 - $2000 \mathrm{mdpl}$ berada pada ancaman tinggi, dan dibuktikan adanya beberapa longsoran eksisting di sekitar kaldera (Sinarta dkk., 2016).

Parameter dalam analisis AHP akan berbeda tergatung pada peneliti dan kondisi lokasi penelitian. Penelitian dengan menggunakan data geospasial dengan lokasi yang luas akan berbeda parameternya pada lokasi yang lebih sempit, sebagai contoh penelitian menggunakan data geospasial di Mancang Pacar, Nusa Tenggara Timur menggunakan parameter kemiringan lereng, jenis batuan, zona sesar (patahan), tata guna lahan, distribusi gerakan tanah (kejadian gerakan tanah), kegempaan, dancurah hujan menampilkan kemiringan lereng sebagai faktor paramter dominan, dengan nilai $\mathrm{CR}$ dibawah $<10 \%$, penelitian ini menunjukan bahwa wilayah mancang pacar sebagian besar berada pada zona kerentanan gerakan tanah menengah seluas $147,65 \mathrm{~km}^{2}$ (33,53\%) dan merupakan wilayah yang mempunyai proporsi kejadian gerakan tanah $10-25 \%$ dari total populasi kejadian. Zona kerentanan tinggi memiliki proporsi kejadian lebih dari $25 \%$ menunjukan bahwa pembobotan dengan AH P tidak bertolak belakang dari kondisi di lapangan dan dapat digunakan (Febriarta \& Wibowo, 2021).

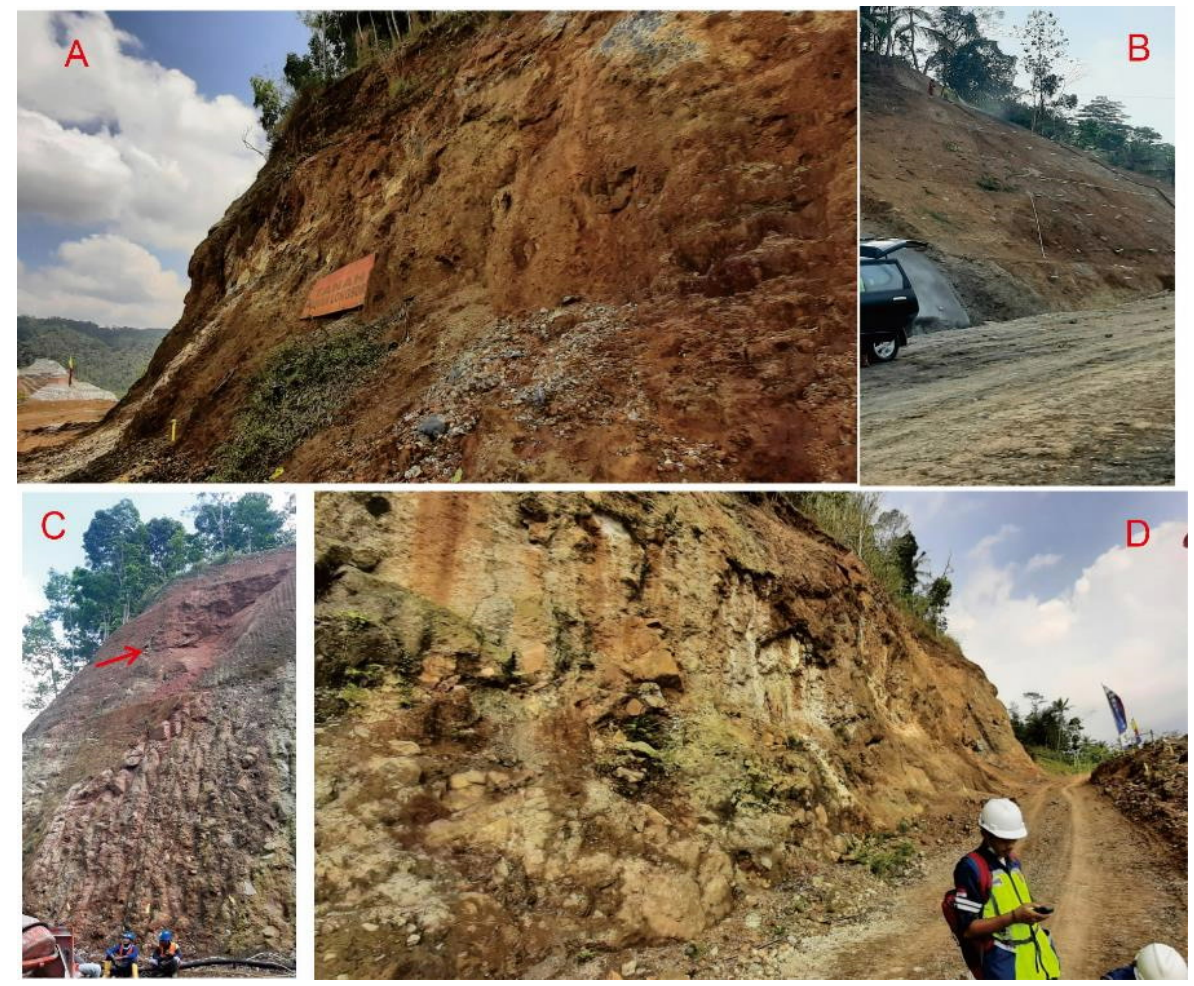

Gambar 4. $A \& D$ Lereng dengan tingkat kerentanan tinggi, B. Penanganan lereng dengan shortcrete pada lokasi zona kerentanan tinggi, C. Longsoran mengikuti pola struktur geologi batuan asal. 
Penelitian di lokasi dengan dominasi batuaN sedimen seperti batupasir dilakukan di daerah Sukatani dan Sekitarnya di Kabupaten Purwakarta, menggunakan parameter litologi, struktur, kemiringan lereng, relief relatif, kebasahan lahan dan tutupan lahan, memunculkan kemiringan lereng sebagai parameter dominan. Selain menguji nilai $C R$ Penggunaan AHP diuji kefektifannya dengan melakukan verifikasi longsoran dengan melakukan pengamtan di lapangan bahwa longsoran dikontrol oleh kemiringan yang curam sebagai faktor utama penyebab (M isbahudin dkk., 2017).

Penelitian kali ini dilakukan di lokasi proyek pembangunan bendungan. Karakteristik lokasi ini berbeda dengan penelitian penelitian yang telah disebutkan sebelumnya. Lokasi penelitian yang lebih sempit memiliki tujuan yang lebih spesifik untuk mendukung dalam pelaksanaan proyek, dan mengandalkan data data detail yang ada seperti pemetaan geologi teknik detail dan pemetaan geologi detail. Pemetaan geologi teknik menghasilkan data persebaran kualitas massa batuan yang muncul sebagi faktor dominan. Hal ini sesuai dengan kondisi yang sebagian besar lokasi pembangunan bendungan memiliki tanah penutup yang relatif tipis antara 1-5 meter, dan tanah tersebut memiliki kuat geser yang cukup tinggi.

Verifikasi efektifitas dari AH P penelitian ini dilakukan dengan verifikasi numeris dan verifikasi kondisi lapangan. Kemiringan lereng menjadi faktor kedua pengontrol longsoran pada lokasi penelitian setelah kualitas massa batuan dan terbukti bahwa beberapa lokasi galian tegak memiliki waktu bendiri (standup time) yang cukup lama selama kualitas massa batuan baik sebaliknya justru Iongsoran mengikuti pola bidang lemah bidang diskontinyuitas yang merupak bagian utama kontrol dari kualitas massa batuan (Gambar 4c). Lokasi yang ditandai rawan longsor berada pada lokasi dengan batuan yang memiliki nilai kualitas yang buruk.

Perhitungan numeris untuk mengkonfirmasi penggunaan metode ini dalam penentuan kerentanan lereng dilakukan pada inti bendungan yang merupakan lokasi dengan kerentanan sedang. Hasil perhitungan numeris analisis stabilitas lereng pada kerentanan lereng sedang menunjukan nilai angka aman lebih dari 2 (Gambar 5). Beberapa hal diatas menunjukan bahwa analisis AHP dapat digunakan untuk analisis kerentanan lereng pada lokasi yang spesifik dengan data detail karena tidak ditemukan adanya konstradiksi kondisi lapangan dengan zonasi kerentanan lereng dengan metode AHP.

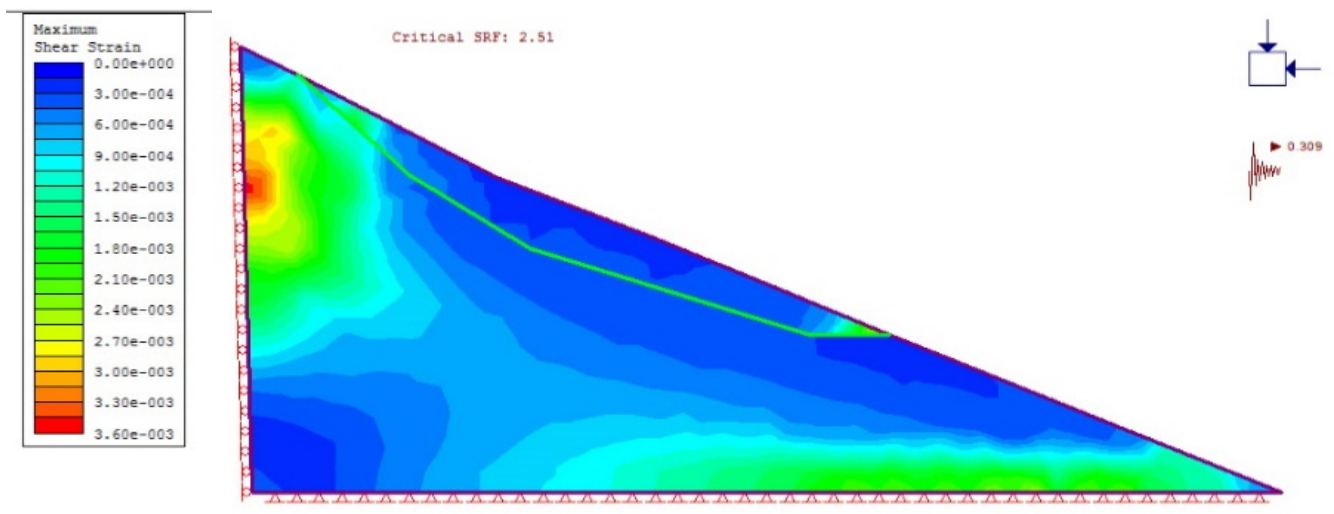

Gambar 5. A nalisis numerik pada lokasi as bendungan dengan konsisi kerentanan lereng sedang. 


\section{KESIMPULAN}

a. Pembobotan dengan metode Analisis AHP dapat dilakukan dan digunakan untuk memetakan kerentanan lereng di lokasi yang spesifik seperti area pembangunan bendungan. berdasarkan analisis tersebut lokasi penelitian tersusun oleh empat zona kerentanan zona kerentanan lereng sangat rendah (5\%), zona kerentanan lereng rendah (25\%), zona kerentanan lereng sedang (50\%), zona kerentanan lereng tinggi (20\%).

b. Lokasi pembangunan bendungan inti dan terowongan berada pada daerah dengan tingkat kerentanan rendah dan sedang, namun sebagian besar berada pada zona kerentanan lereng rendah sehingga tidak memerlukan penanganan khusus saat ekskavasi saat konstruksi. Lokasi dengan tingkat kerentanan rendah berada pada bagian tengah lokasi penelitian membentang dari utara ke selatan yang merupakan lokasi daerah aliran sungai dan sekitarnya.

c. Rencana lokasi genangan berada pada daerah dengan tingkat kerentanan lereng rendah, sehingga jika terjadi rapid draw down pada lokasi genangan kemungkinan kecil mempengaruhi stabilitas dari lereng disekitar genangan, hal tersebut menguntungkan karena meminimalisir adanya laju sedimentasi pada bendungan yang disebabkan karena material longsor.

d. Diperlukan penelitian selanjutnya untuk mengkonfirmasi lokasi dengan 4 katagori kerentanan dengan melakukan evaluasi analisis numeriknya.

\section{UCAPAN TERIMA KASIH}

Penulis mengucapkan terima kasih kepada pihak pihak yang terlibat pada penelitian ini antara lain Jajaran Direksi Politeknik Pekerjaan Umum, Kepala Balai Besar Wilayah Sungai Serayu Opak dan jajarannya di satuan kerja bendungan serta semua pihak yang mendukung yang tidak dapat disebutkan satu per satu.

\section{DAFTAR PUSTAKA}

BBWS Serayu Opak. (2018). Laporan geologi. September.

Bieniawski, Z. T. (1989). Engineering Rock Mass Classifications Wiley \& Sons, New York, p. 251.

http://www.dot.ca.gov/hq/esc/geotech/refere nces/Rockfall_References/05_Bieniawski_Eng Rx_M ass_Classification.pdf

BS 5930. (2009). Code of practice for site investigations. British Standards Institution, 1-192.

Ercanoglu, M., Kasmer, O., \& Temiz, N. (2008). Adaptation and comparison of expert opinion to analytical hierarchy process for landslide susceptibility mapping. Bulletin of Engineering Geology and the Environment, 67(4), 565-578.

https://doi.org/10.1007/s10064-008-0170-1

Febriarta, E., \& Wibowo, Y. A. (2021). Kerentanan Gerakan Tanah Menggunakan Teknik Geospasial Statistik Di Macang Pacar, Nusa Tenggara Timur. Jurnal Geografi, 18(1), 9-20. https://doi.org/10.15294/jg.v18i1.26234

Hoek, E., \& Brown, E. T. (2019). The H oek-Brown failure criterion and GSI - 2018 edition. Journal of Rock Mechanics and Geotechnical Engineering, 11(3), 445-463.

https://doi.org/10.1016/j.jrmge.2018.08.001

Indriani, Y.N., Sari Bahagiarti Kusumayudha. Heru Sigit Purwanto. (2017). Analisis Gerakan Massa Berdasarkan Sifat Fisik Tanah. Mineral, Energi Dan Lingkungan, 1(2), 39-49.

Menteri Pekerjaan Umum. (2007). Peraturan Menteri Pekerjaan Umum No 22/PRT/M /2007 Tentang Pedoman Penataan Ruang Kawasan Rawan Bencana Longsor. Peraturan Menteri Pekerjaan Umum No.22/Prt/M/2007, 22, 1-148.

M isbahudin, Husna, A., Toriq, R., \& Marwantho, A. (2017). Analisis kerentanan longsoran menggunakan proses hirarki analitik di daerah Sukatani dan sekitarnya, Kabupaten Purwakarta, Jawa Barat. Jurnal Lingkungan 
Dan Bencana Geologi, 8(1), 19-30.

Pratiwi, R. B. (2019). EVALUASI PENGARUH BATUAN TERALTERASI TERHADAP KERENTANAN LONGSOR DI JALAN JALUR PONOROGO - TRENGGALEK Km. $16+200-K m$. 23, PROVINSI JAWA TIMUR.

Romana, M ., Tomás, R., \& Serón, J. B. (2015). Slope Mass Rating (SMR) geomechanics classification: Thirty years review. 13th ISRM International Congress of Rock Mechanics, 2015-MAY (M ay), 1-10.

Saaty, T. L. (2002). Decision making with the Analytic Hierarchy Process. Scientia Iranica, 9(3), 215-229. https://doi.org/10.1504/ijssci.2008.017590

Sasangka, D. J. (2021). Analisis M etode Ekskavasi Terowongan Pengelak Bendungan Bener Berdasarkan Data Geologi Teknik. 9(85), 1324.

Sasangka, D. J., Indrawan, I. G. B., Taufik, R., \& Insani, D. (2019). Modelling of Engineering Geology Condition of Bener Dam Diversion Tunnel Based on Surface and Subsurface Data Ministry of Public W orks and Housing of the Republic of Indonesia , 2 Gadjah Mada University. JCY, 1-6.

Sasangka, D. J., Insani, D., \& Indrawan, I. G. B. (2020). Engineering Gology Model of Bener Dam Diversion Tunnels in Geological Risk Disaster Mitigation. Jurnal Geofisika Eksplorasi, 6(3), 205-215. https://doi.org/10.23960/jge.v6i3.95

Sinarta, I. N., Rifai, A ., \& W ilopo, W . (2016). Indeks Ancaman Gerakan Tanah dengan Metode Analytic Hierarchy Process ( AHP) untuk Penataan Infrastruktur Kepariwisataan di Kawasan Geopark Gunung Batur, Kabupaten Bangli. Semin. Nas. KonsepSi\#2 (Konsep Dan Implementasi 2), Vol.1(1), 1-10. http://repository.warmadewa.ac.id/id/eprint/ 365/

Sivakugan, N. Kumar, S. Das, B. M. (2004). Rock Mechanics. In Encyclopedia of Geology. https://doi.org/10.1016/B0-12-3693969/00224-0

Todd, M. K. (2014). Rock mass classification systems. Handbook of Geotechnical Investigation and Design Tables, January 2015, 287-304.

https://doi.org/10.1201/b16520-20

Zuidam, R. A. van. (1986). A erial photointerpretation in terrain analysis and geomorphologic mapping / Robert A. van Zuidam, with contributions from F.I. van Zuidam-Cancelado and other members of the staff of the International Institute for Aerospace Survey and Earth Sciences (ITC. Smits, Publishers. 